\title{
A new fish species of Roeboides from Panamá (Characiformes: Characidae)
}

\author{
Carlos Alberto S. de Lucena \\ Laboratório de Ictiologia, Museu de Ciências e Tecnologia da PUCRS. Av. Ipiranga 6681, 90619-900, Porto Alegre, \\ RS, Brazil; lucena@pucrs.br
}

Received 25-X-2010. C Corrected 18-IV-2011. Accepted 20-V-2011.

\begin{abstract}
A freshwater fish Roeboides loftini n.sp. is described from the Río Coclé del Norte drainage of the Atlantic versant of Panamá. The new species differs from other species of the Roeboides guatemalensis-group by the number of perforated scales on the lateral line (83-100), body depth (31.8-36.1\%), predorsal distance (49.1-51.9\%) and the shape of the humeral spot. Rev. Biol. Trop. 59 (4): 1663-1667. Epub 2011 December 01.
\end{abstract}

Key words: distribution, freshwater fish, Río Coclé del Norte, Atlantic versant.

The genus Roeboides Günther, 1864 comprises a monophyletic assemblage of 16 valid species occurring in Central and South America. Six Central American species $(R$. dayi Steindachner, 1878, R. guatemalensis Günther, 1864, R. occidentalis Meek \& Hildebrand, 1916, R. bouchellei Fowler, 1923, R. ilsea Bussing, 1985, \& R. carti (Lucena 2000) along with $R$. dientonito Schultz, 1944 from Lago Maracaibo, the Río Orinoco drainage and rivers of Northwestern Guyana, compose the $R$. guatemalensis-group (Lucena 2007).

Among the synapomorphies that support the Roeboides guatemalensis-group are: the presence of infraorbitals 4 and 5, the presence of cusps on the teeth of the inner tooth series of the premaxilla; the absence of D4 teeth of the dentary (Lucena 1998); a long, slender projection on the lower posterior margin of cleithrum slightly surpassing the first pectoral-fin ray, and a humeral spot located posterior to the vertical through the middle of the pectoral fin (Lucena submitted).

Lucena (2000) examined a few young specimens in poor condition from the Río Coclé del Norte drainage (Río Tambo) and identified them as Roeboides sp. He pointed out some differences between these specimens and specimens belonging to other species of Roeboides in Central America. The analysis of new samples from that drainage allowed the recognition of a new species of Roeboides, which is described herein.

\section{MATERIAL AND METHODS}

Specimens were collected by Jorge Garcia, Universidad de Panamá and were deposited at the Museu de Ciências e Tecnologia da Pontifícia Universidade Católica do Rio Grande do Sul, Porto Alegre, Brazil (MCP) and the Smithsonian Tropical Research Institute, Panama (STRI). Counts and measurements were taken as described by Fink \& Weitzman (1974). A cleared and stained (c\&s) specimen was prepared according to the method of Taylor \& Van Dyke (1985). Vertebral counts included the four vertebrae of the Weberian apparatus and the terminal vertebral centrum was counted as a single element. Measurements are given as percentages of standard length (SL). In the Description, the values of the holotype are cited between brackets and $n$ indicates the number of 
specimens. The comparative material is cited in Lucena (2000).

\section{RESULTS}

\section{Roeboides loftini, new species}

Fig. 1; Table 1

\section{Roeboides sp. Lucena 2000:51 \\ (short diagnosis).}

Holotype: STRI-7655 (65.1mm SL), Río Turbe, tributary of Río San Juan, upper Río Coclé del Norte drainage, Panamá, $08^{\circ} 47^{\prime} 05^{\prime}$ ' N - 80 38'10" W, 2009, Jorge Garcia.

Paratypes: STRI-7656 (3, 44.4-64.6mm SL), same locality as holotype; STRI-7657 (14, 39.7-80.2mm SL, 1 c\&s specimen, $65.0 \mathrm{~mm}$ SL), Río Turbe, tributary of Río San Juan, upper Río Coclé del Norte drainage, Panamá. 084'09" N - 80 37'55" W, MCP 45775 (3, 57.7-75.1mm SL), same locality as STRI-7657.

Non-types: STRI $400(9,35.0-65.1 \mathrm{~mm}$ SL), Río Tambo, Río Coclé del Norte drainage, Panamá (Lucena, 2000).

Diagnosis: Roeboides loftini is a member of the $R$. guatemalensis-group. It differs from $R$. occidentalis, $R$. dayi, and $R$. dientonito by the number of lateral line scales $(83-100$ vs. 51-80), from $R$. dayi and $R$. dientonito by the number of scale rows above the lateral line (20-22 vs. 10-18) and around the caudal peduncle (27-30 vs. 17-24), and from $R$. dientonito by the number of scale rows below the lateral line (20-24 vs. 17-21). Roeboides loftini differs from $R$. ilsea, a species with a high number of lateral line scales (84-93), by the lower body depth $(31.8-36.1 \%$, mean $=33.7 \%$ vs. $36.9-41.8 \%$, mean $=38.8 \%)$ and shorter predorsal distance $(49.1-51.9 \%$, mean $=50.4 \%$ vs. $51.4-55.9 \%$, mean $=52.9 \%$ ). Roeboides loftini differs from other Central American species, $R$. bouchellei, $R$. guatemalensis and $R$. carti in the shape of the humeral spot. Roeboides bouchellei exhibits a small, sometimes inconspicuous, slightly vertically elongate humeral spot, extending over 3 or 4 horizontal rows of scales and 2 or 3 vertical rows, whereas $R$. loftini exhibits a conspicuous, slightly rounded humeral spot extending over 5-7 horizontal rows of scales and 5-8 vertical rows. In addition, $R$. loftini has a tenuous, short extension on the anterodorsal portion of the humeral spot (Fig. 1) which is absent in $R$. bouchel$l e i$. The humeral spot of $R$. carti reaches or surpasses the vertical through the origin of the anal fin and, in adults, extends posteriorly to the vertical through the origin of the dorsal fin (Lucena 2000). Roeboides guatemalensis has a large, anteriorly sometimes bifurcate, black stripe, extending between the vertical through the middle of the pelvic fin and the vertical near the posterior terminus of the base of the dorsal fin (Lucena 2000). Roeboides loftini differs from $R$. carti and $R$. guatemalensis by its rounded humeral spot located far from the verticals through the origins of the dorsal and anal fins (5-8 and 3-5 vertical series of scales, respectively).

Description: Table 1 presents the morphometric data for the holotype and 20 paratypes. Predorsal profile elevated and convex from base of supraoccipital process to dorsal fin origin; posteroventrally sloped along dorsal-fin base and straight from terminus of dorsal fin base to caudal peduncle. Ventral profile convex from lower lip to anal fin origin; straight along anal fin base. Mouth subterminal with lower jaw slightly shorter than upper jaw. Snout profile convex from dorsal view. Maxilla expanded anteroposteriorly, extending posteriorly to vertical through middle of orbit or slightly beyond that point. Premaxilla with two large mamilliform teeth projecting anteriorly from each side of upper jaw at margin of lip. Rows of teeth irregular. Outer row with 4 to 6 conical teeth, rarely with side cusps. Inner row with 3 to 5 mamilliform-like teeth with two small lateral cusps. Maxilla with 9-14 teeth; first five to seven conic with one or two mamilliform teeth displaced towards lateral surface of bone and 


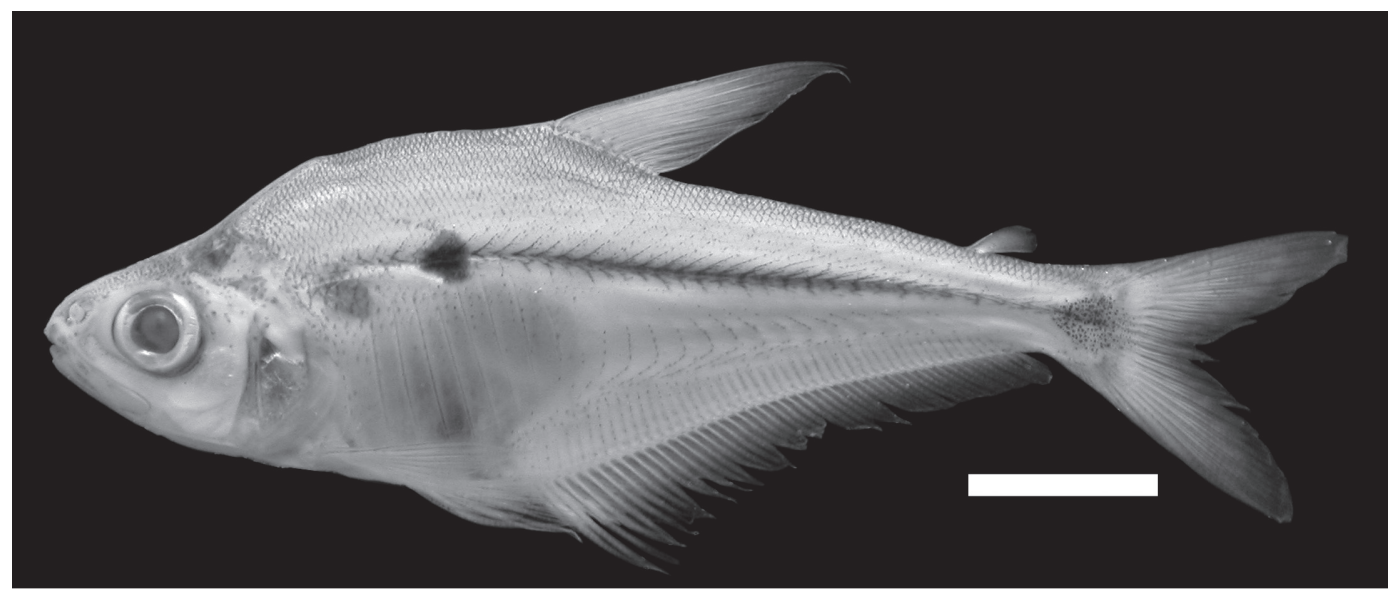

Fig. 1. Roeboides loftini n. sp., STRI-7655 (65.1 mm SL), holotype, Río Turbe, tributary of Río San Juan, upper Río Coclé del Norte drainage, Panama. Scale bar $=10 \mathrm{~mm}$.

TABLE 1

Morphometric data for Roeboides loftini, n. sp., $\mathrm{n}=20$ for all values of paratypes

\begin{tabular}{|c|c|c|c|c|c|}
\hline & \multirow{2}{*}{ Holotype } & \multicolumn{3}{|c|}{ Paratypes } & \multirow[b]{3}{*}{ SD } \\
\hline & & \multicolumn{3}{|c|}{ Range } & \\
\hline Measurement & & low & high & mean & \\
\hline \multirow[t]{2}{*}{ Standard length (mm) } & 65.1 & 44.4 & 80.2 & 61.2 & \\
\hline & \multicolumn{5}{|c|}{ percents of standard length } \\
\hline Body depth & 35.3 & 31.8 & 36.1 & 33.7 & 1.263 \\
\hline Predorsal length & 50.3 & 49.1 & 51.9 & 50.4 & 0.805 \\
\hline Preanal length & 46.3 & 44.5 & 50.0 & 47.6 & 1.608 \\
\hline Prepectoral fin length & 27.0 & 24.9 & 34.1 & 26.9 & 2.184 \\
\hline Prepelvic fin length & 36.7 & 33.1 & 39.5 & 35.6 & 1.425 \\
\hline Caudal peduncle length & 8,1 & 8.1 & 10.7 & 9.5 & 0.740 \\
\hline Caudal peduncle depth & 8,1 & 6.3 & 8.4 & 7.5 & 0.493 \\
\hline \multirow[t]{2}{*}{ Head length } & 28.2 & 24.5 & 28.3 & 26.1 & 0.895 \\
\hline & \multicolumn{5}{|c|}{ percents of head length } \\
\hline Snout length & 26.6 & 23.0 & 30.2 & 26.4 & 2.164 \\
\hline Orbital diameter & 32.0 & 31.2 & 39.5 & 34.8 & 2.160 \\
\hline Upper-jaw length & 46.7 & 39.5 & 48.0 & 45.3 & 2.460 \\
\hline Interorbital width & 23.3 & 21.0 & 36.0 & 24.6 & 2.927 \\
\hline
\end{tabular}

followed by conic or mamilliform-like teeth along ventral border of bone. Dentary with one large mamilliform teeth projecting anterolaterally and laterally (Lucena, 1998). Two anteriormost dentary tooth larger, mamilliform, weakly tricuspid and followed by two or three smaller conic and one mamilliform-like tricuspid teeth and then 9-14 smaller conic teeth posteriorly curved lingually.

Gill-rakers long, upper limb with five to seven rakers $(n=20$, mode $=6)[6]$, lower limb with nine or ten rakers $(n=20$, mode $=9)$ [9]. 
Dorsal fin rays $i+9 \quad(n=20)$. Fin origin situated approximately slightly beyond vertical through origin of anal fin. Anal fin rays iv-v, 45-50 ( $n=20$, mode=47) [46]. Males with one or two small, retrorse bony hooks per segment on first to seventh or eighth segmented rays. Pectoral fin rays $i+12-14 \quad(n=19$, mode=13) [12]. Tip of longest ray falling slightly short of, or reaching, anal fin origin. Pelvic fin rays i,7 $(n=20)$. Longest pelvic ray extending beyond anal fin origin. Males with one bony hook per segment present from first to seventh segmented anal fin rays. Caudal fin forked with 19 principal rays $(n=20)$.

Lateral line scales 83-100 $\quad(n=20$, mode $=88 / 89$ ) [85]. Scale rows above lateral line 20-22 $(n=20$, mode $=20)$ [21]; scale rows below lateral line 20-24 $(n=19$, mode $=22)$ [22]; scale rows around caudal peduncle 25-30 $(n=10$, mode $=29 / 30)$ [20]. Precaudal vertebrae 15 ; caudal vetrabrae 23 ; total vertebrae $38(n=1$ c\&s specimen).

Color in alcohol: Ground color yellowishtan. Dorsal portions of head and body densely pigmented dark brown. Conspicuous dark lateral band extending between margin of opercle and caudal fin base. Expanded posteriorly into large spot on caudal peduncle. Slightly dusky lateral band situated anterior of humeral spot. Most specimens with chromatophores concentrated along the myosepta within lateral band resulting in chevron-shaped marks. Conspicuous black humeral spot distinctly separated from verticals through origins of dorsal and anal fins by 5-8 and 3-5 rows of scales, respectively. Humeral spot in well-preserved specimens shows faint dorsal, anteriorly-oriented extension. Fins, especially dorsal and anal fins, dusky.

Color in life: Overall coloration silvery or yellowish. Tip of snout black. Dark midlateral stripe sometimes inconspicuous and hidden by silvery lateral band. Dark humeral spot conspicuous. Caudal peduncle spot dark diffuse. Caudal fin yellow. Tip of caudal-fin rays clear. Other fins slightly yellowish.
Etymology: The specific epithet, loftini, is a patronym in honor of Dr. Horace Loftin in recognition of his contributions to our knowledge of the distribution of the freshwater fishes of Panamá.

Distribution: The species is known only from the Río Coclé del Norte drainage, an Atlantic versant drainage of Northwestern Panamá.

\section{DISCUSSION}

Roeboides loftini has an incomplete infraorbital series. One of the synapomorphies of the $R$. guatemalensis-group is a complete infraorbital series with the presence of the fourth and fifth infraorbitals (Lucena submitted). The condition present in R. loftini may be parsimoniously considered an autapomorphy.

In addition to $R$. loftini, five species of Roeboides occur in Panamá, all showing disjunct distributions: $R$. dayi, $R$. guatemalensis, and $R$. carti from the Atlantic versant, and $R$. occidentalis and R. bouchellei, from the Pacific versant. Along the Atlantic versant of Panamá, the Río Coclé del Norte drainage represents the westernmost occurrence of Roeboides. $R$. bouchellei, another species that may occur in the Atlantic drainages of Central America, has its distribution from Río Matina, Costa Rica (Bussing 2002) to the Río Negro drainage (or Río Sico Tinto), Honduras (Matamoros et al. 2009). This apparent gap in the Atlantic versant distribution of Panamá may be due to the lack of collections in that area. Roeboides is absent along the Atlantic coast of Central America North from Río Negro, Honduras.

\section{ACKNOWLEDGMENTS}

I am grateful to the following: Jorge García, Universidad del Panamá, for sending the specimens that served as the basis of the description of the new species; Rigoberto Gonzáles G., for his help in sending specimens since 1999 and for the suggestion of the specific 
epithet; Oris Sanjur and Gisela Reina of STRI, for cataloging the type series. Fernando Jerep provided the photo of the holotype.

\section{RESUMEN}

Roeboides loftini n.sp., se describe en la desembocadura del río Coclé del Norte en la Vertiente Atlántica de Panamá. La nueva especie se diferencia de otras especies del grupo del Roeboides guatemalensis, por el número de escamas perforadas en la línea lateral (83-100), la profundidad del cuerpo (31.8-36.1\%), distancia predorsal (49.1$51.9 \%$ ) y la forma de la mancha humeral.

Palabras clave: distribución, peces de agua dulce, Río Coclé del Norte, vertiente del Atlántico.

\section{REFERENCES}

Bussing, W.A. 2002. Peces de las aguas continentales de Costa Rica. Universidad de Costa Rica, San Pedro, Costa Rica.
Fink, W.L \& S.H. Weitzman. 1974. The so-called Cheirodontin fishes of Central America with descriptions of two new species (Pisces: Characidae). Smithson. Contrib. Zool. 172: 1-46.

Lucena, C.A.S. 1998. Relações filogenéticas e definição do gênero Roeboides Günther (Ostariophysi: Characiformes: Characidae). Comun. Mus. Ciênc. Tecnol. PUCRS 11: 19-59.

Lucena, C.A.S. 2000. Revisão taxonômica e filogenia das espécies transandinas do gênero Roeboides Günther (Teleostei: Ostariophysi: Characiformes). Comun. Mus. Ciênc. Tecnol. PUCRS 13: 3-63.

Lucena, C.A.S. 2007. Revisão taxonômica das espécies do gênero Roeboides grupo-affins (Ostariophysi, Characiformes, Characidae). Iheringia 97: 117-136.

Matamoros, W.A., J.F. Schaefer \& B.R. Kreiser. 2009. Annotated checklist of the freshwater fishes of continental and insular Honduras. Zootaxa 2307: 1-38.

Taylor, W.R. \& G.C. Van Dyke. 1985. Revised procedures for staining and clearing small fishes and other vertebrates for bone and cartilage study. Cybium 9: 107-119. 
